28 Ferrannini $\mathrm{E}$, Haffner SM Stern MP Essential hypertension: an insulin-resisant state. 7 Cardiovasc Pharmacol 1990;15(suppl 5): 18-25.

9e Fronzo RA. The effect of insulin on renal sodium metabolism: a review with clinica implications. Diabetologia 1981;21:165-71.

30 Landsberg L. Diet, obesity and hypertension: an hypothesis involving insulin, the sympathetic nervous system, and adaptive thermogenesis. $Q \mathcal{F}$ Med 1986;61:1081-90.

1 Halkin $H$, Modan $M$, Shefi $M$, Almog S. Altered erythrocyte and plasma sodium and potassium in hypertension, a facet of hyperinsulinemia. Hypertension 1988;11:71-7.

$32 \mathrm{Klip}$ A, Ramlal T, Cragoe EJ Jr. Insulin-induced cytoplasmic alkalinization and glucose transpor in muscle cells. Am f Physiol 1986;250(Cell Physiology 19):C720-8.

33 Nagi DK, Hendra TJ, Ryle AJ, Cooper TM, Temple RC, Clark PMS, et al. The relationships of concentrations of insulin, intact proinsulin and 32,33 split proinsulin with cardiovascular risk factors in type 2 (non-insulin-dependent) diabetic subjects. Diabetologia 1990;33:532-7.

34 Pollare T, Lithell H, Berne C. A comparison of the effects of hydrochlorothiazide and captopril on glucose and lipid metabolism in patients with hypertension. $N$ Engl f Med 1989;321:868-73.

35 Pollare T, Lithell $\mathrm{H}$, Selinus I, Berne C. Sensitivity to insulin during treatment with atenolol and metoprolol: a randomised, double blind study of the effects on carbohydrate and lipoprotein
metabolism in hypertensive patients. $B M \mathcal{F} 1989 ; 298: 1152-7$.

36 Yudkin JS, Alberti KGMM, McLarty DG, Swai ABM. Impaire

udkin JS, Alberti KGMM, McLarty DG, Swai ABM. Impaired glucose tolerance: is it a risk
factor for diabetes or a diagnostic ragbag? $B M \mathcal{1}$ 1990;301:397-402. adowaki T, Miyake Y, Hagura R, Akanuma Y, Kajinuma H, Kuzuya N, et al. Risk factors for worsening to diabetes in subjects with impaired glucose tolerance. Diabetologia 1984;26:44-9. Sicree RA, Zimmet PZ, King HOM, Coventry JS. Plasma insulin response among Nauruans: prediction of deterioration in glucose tolerance over $6 \mathrm{yr}$. Diabetes 1987;36:179-86.

99 Saad MF, Knowler WC, Pettitt DJ, Nelson RG, Mott DM, Bennett PH. The natural history of impaired glucose tolerance in the Pima Indians. N Engl f Med 1988;319:1500-6.

40 Pollare $\mathrm{T}$, Lithell $\mathrm{H}$, Berne $\mathrm{C}$. Insulin resistance is a characteristic feature of primary hypertension independent of obesity. Metabolism 1990;39:167-74

41 Amery A, Berthaux XP, Bulpitt C, Deruyttere M, De Schaepdryver A, Dollery C, et al. Glucose intolerance during diuretic therapy. Results of trial by the European Working Party on Hypertension in the Elderly. Lancet 1978;i:681-3.

42 Amery A, Birkenhäger W, Brixko P, Bulpitt C, Clement D, Deruyttere M, et al. Glucose intolerance during diuretic therapy in elderly hypertensive patients. A second report from the European Working Party on High Blood Pressure in the Elderly (EWPHE). Postgrad Med $\mathcal{F}$ 1986;62:919-24

43 Medical Research Council Working Party. MRC trial of treatment of mild hypertension: principal results. BMF 1985;291:97-104.

44 Medical Research Council. Report of Medical Research Council Working Party on Mild to Moderate Hypertension. Adverse reactions to bendrofluazide and propranolol for the treatment Moderate Hypertension. Adverse reactions to
of mild hypertension. Lancet 1981;ii:539-43.

45 Helgeland A, Leren P, Foss OP, Hjermann I, Holme I, Lund-Larsen PG. Serum glucose level during long-term observation of treated and untreated men with mild hypertension. The Oslo during long-term observation of
Study. Am J Med 1984;76:802-5.

46 Grimm RH Jr, Cohen JD, McFate Smith W, Falvo-Gerard L, Neaton JD. Hypertension management in the multiple risk factor intervention trial (MRFIT). Six year intervention results for men in special intervention and usual care groups. Arch Intern Med 1985;145:1191-9.

47 Pyörälä K. Relationship of glucose tolerance and plasma insulin to the incidence of coronary heart disease: results from two population studies in Finland. Diabetes Care 1979;2:131-41.

48 Welborn TA, Wearne $\mathrm{K}$. Coronary heart disease incidence and cardiovascular mortality in Busselton with reference to glucose and insulin concentrations. Diabetes Care 1972;2: $154-60$.

49 Ducimetiere P, Eschwege E, Papoz L, Richard JL, Claude JR, Rosselin G. Relationship of plasma insulin levels to the incidence of myocardial infarction and coronary heart disease mortality in middle-aged population. Diabetologia 1980;19:205-10.

5ó Stout RW. Insulin and atheroma -an update. Lancet 1987;i: 1077-9.

51 Lever AF. Slow pressor mechanisms in hypertension: a role for hypertrophy of resistance vessels? f Hypertens 1986; 4:515-24.

52 Levy D, Garrison RJ, Savage DD, Kannel WB, Castelli WP. Prognostic implications of echocardiographically determined left ventricular mass in the Framingham heart study. $N$ Engl $\mathcal{f}$ Med 1990;322:1561-6.

53 Poulter N, Sever P, Thom S. Antihypertensive and adverse biochemical effects of bendrofluazide. BMF 1990;300: 1465 .

54 Black HR. The coronary artery disease paradox: the role of hyperinsulinemia and insulin resistance and implications for therapy. $\mathcal{f}$ Cardiovasc Pharmacol 1990;15(suppl 5):26-38.

55 Collins R, Peto R, MacMahon S, Hebert P, Fiebach NH, Eberlein KA, et al. Blood pressure, stroke, and coronary heart disease. Part 2. Short-term reductions in blood pressure: overview of randomised drug trials in their epidemiological context. Lancet 1990;335:827-38.

56 Erne P, Resink TJ, Bürgisser E, Bühler FR. Platelets and hypertension. 7 Cardiovasc Pharmacol 1985; 7(suppl 6):103-8.

57 Landin K, Tengborn L, Smith U. Elevated fibrinogen and plasminogen activator inhibitor (PAI-1) in hypertension are related to metabolic risk factors for cardiovascular disease. $\mathcal{J}$ Intern Med 1990;227:273-8.

58 MacMahon S, Peto R, Cutler J, Collins R, Sorlie P, Neaton J, et al. Blood pressure, stroke, and coronary heart disease. Part 1. Prolonged differences in blood pressure: prospective observational studies corrected for the regression dilution bias. Lancet 1990;335:765-74.

59 Hopper JL, Pathik B, Hunt D, Chan WWC. Improved prognosis since 1969 of myocardial infarction treated in a coronary care unit: lack of relation with changes in severity. $B M \gamma$ 1989;299:892-6.

60 ISIS-2 (Second International Study of Infarct Survival) Collaborative Group. Randomised trial of intravenous streptokinase, oral aspirin, both, or neither among 17187 cases of suspected acute myocardial infarction: ISIS-2. Lancet 1988;ii:349-60.

61 Brown MJ. Brown J. Does angiotensin-II protect against strokes? Lancet 1986;ii:427-9.

62 Pollare T, Lithell H, Selinus C, Berne C. Application of prazosin is associated with an increase of insulin sensitivity in obese patients with hypertension. Diabetologia 1988;31:415-20.

63 British Hypertension Society Working Party. Treating mild hypertension: agreement from the large trials. BMF 1989;298:694-8.

64 Swales JD. First line treatment in hypertension: still $\beta$ blockers and diuretics. $B M \gamma$ $1990 ; 301: 1172-3$

\title{
Addressing the most important preventable cause of death
}

\section{A new journal on tobacco control}

What is the most important health problem today? The candidates are many: HIV infection-for its case fatality rate, rapid spread throughout the world, and complex social effects; use of alcohol and illicit drugs - for its contribution to violence, health care costs, family disruption, and social degradation; injuries-the commonest cause of years of potential life lost in some countries ${ }^{1}$; or lack of exercise - the most prevalent risk factor for heart disease. ${ }^{2}$ The multiplicity of health indices makes it possible to label almost any disease, pathogen, chemical, behaviour, or consumer product as the most important health problem. But if we go back to basicsand consider deaths - then tobacco stands out. Tobacco use is the leading preventable cause of death in developed countries and is quickly gaining that distinction in developing countries.

World tobaacco consumption increased from 4.7 million tons in 1975 to 6.6 million tons in 1990 . Consumption is projected to grow by about $2 \%$ each year, reaching 7.9 million tons in the year 2000. Developed countries will experience a slight fall, whereas a $3 \%$ annual growth rate is projected for developing countries. ${ }^{3}$ The largest increases have been in Africa and the Asia-Pacific region, with mean per person cigarette consumption increasing by $25 \%$ and $18 \%$ respectively between 1970 and $1985 .{ }^{4} \mathrm{As}$ a direct result the incidence of disease attributable to tobacco is also rising. A World Health Organisation expert panel has estimated that three million people die every year because of tobacco use. The panel predicts that if current smoking patterns continue the toll will increase to 10 million deaths a year by 2025 . This means that half a billion people now living $-10 \%$ of the world's population - could ultimately die of tobacco use..$^{56}$
These staggering figures can be quoted with confidence because-as Antonia Novello, the United States surgeon general, has noted - "Smoking represents the most extensively documented cause of disease ever investigated in the history of biomedical research." The United States Office on Smoking and Health's bibliographical database contains more than 50000 citations from biomedical publications. This voluminous research has been summarised in more than 8000 pages in 21 reports from the surgeon general. The research has been published in a wide range of journals devoted to general medicine, medical specialties, public health, health education, addiction, psychology, economics, law, health policy, and other disciplines.

Now the subject is to have a journal of its own. To capture important research findings, put them into perspective, and disseminate them to audiences around the world, the BMJ Publications Group is launching a new journal-Tobacco Control (see p 739 and a call for papers facing p 759 in the clinical research edition, and page 763 in the general practice $\stackrel{\oplus}{\hookrightarrow}$ edition, and on the inside back cover in the international 0 edition). The journal will appear in March 1992 in time for the eighth world conference on tobacco and health in Buenos Aires.

The control of an infectious disease requires an understanding of the causative agent, the vector, the host, and the $\delta$ environment in which transmission occurs. The same applies to controlling tobacco use. ${ }^{8}$ Therefore, Tobacco Control will consider much more than the effects of smoking on health. It will investigate the agent, tobacco, including new productssuch as denicotined cigarettes-designed to appeal to health 
conscious smokers. It will follow the activities of vectorsthose who manufacture, advertise, distribute, and sell tobacco products. The journal will pay attention to the host, publishing epidemiological and behavioural research on tobacco use, and will analyse the environment in which tobacco is used. The impact of tobacco on the environment-for example, on public health, the economy, and political processes - will be considered, as will the impact of the environment on tobacco. Programmes and policies that discourage tobacco consumption are an important part of that environment, and publishing evaluations of these interventions will be a priority for the new journal. Similarly, it will publish survey research on public beliefs, opinions, and attitudes related to tobacco.

Most of the journal will comprise rigorous, peer reviewed science, but there will also be news on activities throughout the world. Tobacco Control will be as international as possible because tobacco and its vectors know no boundaries. As their home markets shrink the transnational tobacco companiesbased predominantly in the United States and Britain-are aggressively marketing their products in the developing world. ${ }^{4-12} \mathrm{~A}$ major goal of the journal will be to report on the developing world.

To emphasise the journal's international aims it will carry the subtitle An International fournal. Its production will involve people all over the world: regional and associate editors and members of the editorial board will represent more than 20 countries from every part of the globe. The editor will be in the United States, the deputy editor in Australia, and the technical editor in Britain. We hope to achieve an even greater geographical diversity among readers and contributors.

RONALD M DAVIS

Chief Medical Officer and Editor of

Tobacco Control: An International fournal,

Michigan Department of Public Health,

Lansing, Michigan 48909

Editor, $B M \mathcal{F}$

RICHARD SMITH

1 National Committee for Injury Prevention and Control. Injury prevention: meeting the challenge. Am F Prev Med 1989; Suppl 5:5.

2 Centers for Disease Control. Protective effect of physical activity on coronary heart disease. $M M W R$ 1987;36:426-30

3 Stevens DJ. Tobacco in the year 2000. Tobacco f Int 1990;3 (May/June):16-22.

4 Chapman S, Leng WW. Tobacco control in the Third World: a resource atlas. Penang, Malaysia: International Organisation of Consumers Unions, 1990.

Peto R, Lopez AD, and the WHO Consultative Group on Statistical Aspects of Tobacco-related Mortality. Worldwide mortality from current smoking patterns. In: Durston B, Jamrozik K, Mortality. World matrozik K, eds. Tobacco and Health 1990-the global war. Perth: Health Department of Western Australia, 1990:66-8. Proceedings of the seventh world conference on tobacco and health.

6 World Health Organisation. Report of a WHO consultation on statistical aspects of tobacco-related mortality, Geneva, 9-13 October 1989. Geneva: WHO, 1990. (Document WHO/TOH/CLH/ 90.2.)

7 United States Department of Health and Human Services. The health benefits of smoking cessation: report of the surgeon general, 1990. Atlanta, Georgia: Centers for Disease Control, Office on Smoking and Health, 1990. (DHHS Publication No. (CDC) 90-8416.)

8 Slade JD. A disease model of cigarette use. $N$ Y State $\mathcal{F}$ Med 1985;85:294-7

9 Dean M. King Tobacco under attack. Lancet 1990;336:865-6.

10 Mackay J. Battlefield for the tobacco war. FAMA 1989;261:28-9.

11 Chen TTL, Winder AE. The opium wars revisited as US forces tobacco exports in Asia Amf Public Health 1990;80:659-62.

12 Davis RM. Promotion of cigarettes in developing countries. FAMA 1986;255:993.

\section{Women in general practice}

\section{Time to equalise the opportunities}

Five out of 10 medical graduates and four out of 10 doctors completing vocational training in general practice are women, yet recent studies suggest that they feel discriminated against - both when applying for posts in general practice and when a practice's workload and profits are shared out ( $p$ 762). ${ }^{12}$ Women with children, who often work part time, feel this most strongly, and many would prefer full time work. Although many women work nominally part time, their rates of consultation and the time they spend with patients are almost identical with those of their male partners. ${ }^{3}$ Two in three work out of hours. ${ }^{2}$

The need to increase the number of women general practitioners was recognised in the government's white paper Working for Patients, published two and a half years ago. ${ }^{4}$ Since then things may have got worse. The new contract for general practitioners, apart from relaxing regulations for maternity leave, has done little to encourage women principals in general practice, and practices may have responded to its pressures by appointing assistants or practice nurses instead.

Women have many attributes which should make them good general practitioners. ${ }^{5}$ Women practitioners are more concerned than men about preventive care, encouraging the uptake of cervical screening and immunisation and promoting health opportunistically. ${ }^{6}$ Patients often prefer a woman doctor, and women perform better than men in the examination for the MRCGP.?

Unfortunately, women's traditional responsibilities for bringing up children account for many of their difficulties. Time out from medicine leads to lack of confidence, both in clinical and in managerial skills. ${ }^{28}$ On returning to work women partners may defer to their male colleagues, an attitude that may persist indefinitely. The retainer scheme may help to provide clinical continuity during these years, but little attention has been given to maintaining and improving managerial skills.

The prospect for improvement seems gloomy, with the government seeking more commitment to late surgeries at times when both men and women want and need to be with their own families. Extending basic practice hours from 20 to 26 and increasing the proportion of income derived from capitation have both worked against women entering general practice. The poor representation of women on the General Medical Services Committee and the council of the Royal College of General Practitioners doesn't help. Although both bodies actively encourage participation by women, few women balancing their career and family can make the necessary commitment.

With applications for vocational training posts falling, now is the time for a radical rethink if a crisis in general practice is to be avoided. What would make general practice more attractive, particularly to women? Improving access to part time training would help, as would identifying suitable hospital posts for part time trainees. Paying a full trainer's grant might encourage practices to take part time trainees: at present, training practices receive only half the grant for supervising and teaching a part time trainee, although most will give an equal amount of tutorial time. There are still few women trainers and course organisers, and recruitment of course organisers is likely to remain low while the present restrictions on pay and workload persist. Little flexibility exists for regional advisers to dedicate course organisers' time to the particular problems of women trainees. 